\title{
Dinamika Kepemimpinan Direktur CV. Dwi Jaya di Desa Sanggalangit Kecamatan Gerokgak Kabupaten Buleleng
}

\author{
IRVAN MUTTAQIEN, WAYAN SUDARTA, I MADE SARJANA \\ Program Studi Agribisnis, Fakultas Pertanian, Universitas Udayana \\ Jl. P.B Sudirman Denpasar \\ E-mail: muttaqien2401@gmail.com \\ sudarta_wayan@ymail.com
}

\begin{abstract}
Leadership Dynamics of CV. Dwi Jaya's Director in Sanggalangit Village, Sub- District of Gerokgak, Buleleng Regency.
\end{abstract}

The success of a company is influenced by the success of its employees. Employee success is influenced by the leadership dynamics of the director. CV Dwi Jaya agribusiness company is one of the companies engaged in the sale of fish seeds in the Sanggalangit Village of Gerokgak Sub-District, Buleleng Regency. The purpose of this research is to determine the level of leadership dynamics of the director and to investigate the levels of the three elements of leadership dynamics of directors in the company of cultivation and sale of fish seeds in CV Dwi Jaya. Descriptive analysis method was used to answer the purpose of the research. Effective human relations, decision-making process and control in leadership are the three variables in leadership dynamics that become the reference in this research. The result of descriptive analysis of leadership dynamics of director of CV Dwi Jaya is classified into a very good category with achievement score of 4.41. This can be seen from the three variables of leadership dynamics. Effective human relationship is categorized as very good with 4.45 achievement score, decision making process is very good with the score of 4.34 and leadership control is quite good with 4.41 score.

Keywords: dynamics, director, leadership.

\section{Pendahuluan}

\subsection{Latar Belakang Masalah}

Pemimpin adalah orang yang memiliki kualitas lebih baik dan berbeda dibandingkan bawahannya. Namun kenyataannya kualitas yang dibutuhkan untuk menjadi seorang pemimpin yang efektif juga dibutuhkan oleh bawahannya. Mereka meninggalkan kepentingan pribadi, dan berani melakukan tindakan yang tepat (Safaria, 2004).

Kepemimpinan merupakan masalah manusia yang bersifat unik. Masalahnya tidak sekedar menyentuh kehidupan manusia sebagai individu, tetapi juga sebagai mahluk sosial. Oleh karena itu, setiap proses kepemimpinan dalam keunikannya masing-masing 
tidak dapat melepaskan diri dari kondisi yang bersifat dan bernilai manusiawi, dalam keadaan seperti itu bila proses kepemimpinan dilaksanakan secara tidak manusiawi, maka berbagai masalah akan terjadi, yang akhirnya akan berakibat prosesnya berlangsung tidak efektif (Rivai, 2008). Dinyatakan oleh Harsey dan Blanchard (dalam Soejono, 1995) bahwa kepemimpinan adalah aktivitas mempengaruhi orang lain untuk secara sukarela berjuang mencapai tujuan kelompok. Kepemimpinan itu sebagai kemampuan mempengaruhi perilaku orang lain. Kata perilaku diartikan luas, perilaku tidak hanya yang terlihat, tetapi pikirannya, keyakinan, sikap mentalnya. Jadi perilaku tidaklah sederhana sebatas tindakan yang terlihat (Setiawan, 2013).

Pemimpin yang baik adalah pemimpin yang mampu membina hubungan baik dengan siapa saja terutama dengan para karyawannya. Hubungan yang diharapkan adalah hubungan yang harmonis, baik dalam hal pelaksanaan tugas, menjalankan keputusan atau perintah, maupun aktivitas diluar pekerjaan. Hal ini dilakukan agar tercapainya tujuan dari proses kepemimpinan yang baik dan dinamis.

Menurut Kartono (2011) pemimpin adalah seorang pribadi yang memiliki kecakapan dan kelebihan khususnya kecakapan dan kelebihan disatu bidang, sehingga dia mampu mempengaruhi orang lain untuk bersama-sama melakukan aktivitasaktivitas tertentu demi pencapaian satu atau beberapa tujuan. Pemimpin dan kepemimpinan tentu tidak lepas dengan apa yang disebut dengan pimpinan, seperti dikemukakan oleh James (1996), pimpinan adalah orang yang bertanggung jawab untuk bekerja dengan orang lain, salah satunya dengan atasannya, staf, teman kerja atau atasan lain dalam organisasi sebaik orang diluar organisasi. Menjadi pimpinan seseorang harus mempunyai visi mengenai sistem sosial yang dipimpinnya. Visi adalah apa yang diimpikan dan apa yang ingin dicapai pada masa yang akan datang. Yukl (2010) menyatakan bahwa visi harus sederhana dan idealistik, visi harus menarik nilai-nilai harapan dan cita-cita anggota organisasi dan para pemegang kepentingan lainnya dalam sebuah organisasi, lebih menekankan pada objektif ideologi jangka panjang dari keuntungan yang akan diperoleh.

Dinamika kepemimpinan direktur perusahaan agribisnis dalam penelitian ini akan menjadi suatu masalah yang diangkat, mengingat bahwa dalam membahas masalah pemimpin tentunya tidak lepas dari masalah kepemimpinan. Pemimpin yang baik adalah pemimpin yang mampu membina hubungan baik dengan siapa saja terutama dengan para karyawannya. Dinamika kepemimpinan merupakan gerak atau perkembangan yang ingin dicapai oleh sekelompok orang dalam upaya mencapai tujuan. Jika terjadi perselisihan dan konflik yang tidak sehat diantara anggota yang dapat mengakibatkan tidak lancarnya roda organisasi, maka seorang pemimpin harus dapat mengatasinya dengan berpedoman pada konstitusi, peraturan dan prosedur yang telah ada.

Menurut Rivai (2008) dinamika kepemimpinan dalam prakteknya dipengaruhi oleh tiga faktor mencakup hubungan manusiawi yang efektif, proses pengambilan keputusan dan pengendalian kepemimpinan. Hubungan manusiawi yang efektif dipengaruhi oleh proses komunikasi dan perlakuan yang menimbulkan rasa senang dan 
puas antara kedua belah pihak. Kondisi seperti ini akan menimbulkan rasa ikut memiliki, rasa ikut bertanggung jawab, dan adanya rasa ikut berpartisipasi, baik pada orang-orang yang dipimpin maupun para pemimpin unit masing-masing (Rivai, 2008). Dengan demikian hubungan manusia yang efektif merupakan faktor penting dalam mewujudkan dinamika kepemimpinan.

Pengambilan keputusan yang akan diwujudkan menjadi kegiatan kelompok merupakan hak dan kewajiban serta tanggung jawab pucuk pimpinan berupa wewenang dan wewenang itu dapat dilimpahkan. Pelimpahan wewenang tidak berarti pihak penerima wewenang boleh membuat keputusan atau melakukan kegiatan sekehendak hatinya, tetapi harus tetap dalam batas norma-norma dan kebijakan umum yang berlaku dalam organisasinya.

Pengendalian kepemimpinan adalah proses dimana manajer pada seluruh tingkatan memastikan bahwa orang-orang yang mereka awasi mengimplementasikan strategi yang di maksud. Kepemimpinan yang efektif dapat dapat terlaksana secara dinamis, karena kemampuan pucuk pimpinan dalam mengambil keputusan-keputusan, yang selalu dirasakan sebagai keputusan bersama. Keputusan seperti ini merupakan bagian dari kegiatan pengendalian dalam kepemimpinan yang memerlukan proses.

\subsection{Rumusan Masalah}

Berdasarkan latar belakang yang ada, maka dapat dirumuskan masalah sebagai berikut.

1. Bagaimana tingkat dinamika kepemimpinan direktur perusahaan pembudidayaan dan penjualan benih ikan CV Dwi Jaya?

2. Bagaimana tingkat ketiga unsur dinamika kepemimpinan direktur tersebut?.

\subsection{Tujuan Penelitian}

Berdasarkan permasalahan tersebut, maka tujuan penelitian ini dapat dikemukakan sebagai berikut.

1. Untuk mengetahui tingkat dinamika kepemimpinan direktur perusahaan pembudidayaan dan penjualan benih ikan CV Dwi Jaya.

2. Untuk mengetahui tingkat ketiga unsur dinamika kepemimpinan direktur tersebut.

\section{Metode Penelitian}

\subsection{Lokasi dan Waktu Penelitian}

Penelitian ini dilakukan di perusahaan pembudidayaan dan penjualan benih ikan di CV Dwii Jaya, Desa Sanggalangit, Kecamatan Gerokgak, Kabupaten Buleleng dengan waktu pengumpulan data yang telah ditentukan yaitu selama tiga bulan yang dimulai pada tanggal 28 Maret 2017 sampai dengan tanggal 14 Juni 2017. Pemilihan Lokasi ini ditentukan secara sengaja (Purposive). 


\subsection{Sumber dan Jenis Data Penelitian}

Penulis dalam penelitian ini menggunakan dua jenis sumber data, yaitu data primer dan data sekunder. Jenis data yang dikumpulkan meliputi data kuantitatif, yakni data berupa angka, misalnya luas lahan, jumlah karyawan CV Dwi Jaya dan data lainnya yang berhubungan dengan penelitian ini, data kualitatif yakni data yang disajikan dalam bentuk kata verbal bukan dalam bentuk angka (Muhadjir, 1996), misalnya keterangan-keterangan dari direktur maupun karyawan CV Dwi Jaya.

\subsection{Instrumen Penelitian}

Instrumen yang digunakan dalam pengumpulan data adalah kuesioner. Kuesioner merupakan instrumen pengumpulan data yang berisikan seperangkat pertanyaan dan pernyataan yang terstruktur tertulis kepada responden untuk dijawab sendiri oleh mereka atau diisi oleh pewawancara dengan tujuan memperoleh informasi tentang pribadi atau hal-hal yang diketahui oleh responden. Kuesioner yang digunakan dalam penelitian ini adalah kuesioner yang bersifat tertutup, dimana responden diminta menanggapi pertanyaan atau pernyataan dengan memilih sejumlah alternatif.

\subsection{Metode Pengumpulan Data}

Pengumpulan data dilakukan dengan cara-cara sebagai berikut.

1. Wawancara merupakan teknik pengumpulan data yang dilakukan melalui kegiatan komunikasi dua arah dengan responden menggunakan daftar pertanyaan (kuisioner), sebelum kuesioner tersebut digunakan, terlebih dahulu dilakukan uji kesahihan dan uji keterandalan kuesioner.

2. Observasi merupakan pengamatan langsung untuk mengamati objek penelitian agar memperoleh gambaran yang jelas untuk mengetahui keadaan yang sesungguhnya dari objek penelitian.

3. Studi dokumentasi yaitu pengumpulan data dengan cara melihat dan mencatat dokumen atau catatan yang berhubungan dengan penelitian sebagai data penunjang.

4. Studi kepustakaan yaitu metode yang digunakan dalam mencari teori-teori dan pengertian melalui buku-buku, literatur, dan media elektronik lainnya yang berkaitan dengan pokok bahasan.

\subsection{Penentuan Populasi dan Responden}

Populasi dalam penelitian ini adalah seluruh karyawan dan kepala divisi yang ada pada CV Dwi Jaya di desa Sanggalangit sebanyak sembilan orang, seluruh populasi itu diambil sebagai responden dengan menggunakan metode sensus.

\subsection{Metode Analisis Data}

Menurut Sugiyono (2010), analisis data merupakan proses mencari dan menyusun secara sistematis data yang diperoleh dari hasil wawancara, catatan lapangan dan 
dokumentasi. Proses analisis data dilakukan dengan menelaah seluruh data yang ada berasal dari berbagai sumber yang meliputi wawancara, observasi, kuisinoner dan studi dokumentasi. Pemberian skor dalam penelitian ini menggunakan skala likert. Skala likert merupakan pengukuran dengan memberikan bilangan bulat 1,2,3,4 dan 5. Skor 1 menyatakan respon sangat tidak baik, skor 2 menyatakan respon tidak baik, skor 3 menyatakan respon sedang, skor 4 menyatakan respon baik dan skor 5 menyatakan respon sangat baik. Dengan rumus Interval sebagai berikut.

$$
I=\frac{\text { Jarak }}{\text { Jumlah kelas }}
$$

Keterangan :

I $\quad$ : Interval kelas

Jarak : Nilai tertinggi dikurangi nilai terendah

Jumlah kelas : Jumlah kategori yang ditentukan

Berdasarkan rumusan di atas diperoleh jarak jumlah kelas dan interval kelas sebagai berikut. $I=\frac{5-1}{5}=0,8$

Jadi interval yang didapat sebesar 0,8

\section{Hasil dan Pembahasan}

\subsection{Karakteristik Responden}

Karakteristik responden merupakan salah satu aspek penting yang berpengaruh dalam dinamika kepemimpinan direktur di CV Dwi Jaya. Responden penelitian ini adalah seluruh karyawan CV Dwi Jaya. Karakteristik responden yang akan dibahas dalam penelitian ini meliputi umur, jenis kelamin, tingkat pendidikan, lama bekerja pada perusahaan, serta jumlah keluarga yang ditanggung.

\subsubsection{Umur}

Menurut Ananta, dkk (1994), struktur umur dibedakan menjadi tiga kelompok, yaitu a) kelompok umur muda, dibawah 15 tahun, b) kelompok umur produktif, usia 15 sampai dengan 64 tahun dan c) kelompok umur tua, usia 65 tahun ke atas. Diantara sembilan orang responden, usia termuda adalah 20 tahun dan usia yang paling tua adalah 45 tahun. Adapun menurut Aris dan Anwar di atas, usia 15 sampai dengan 64 tahun tergolong dalam usia produktif. Hal ini menunjukkan bahwa responden yakni karyawan CV Dwi Jaya mempunyai potensi mengelola perusahaan dengan produktivitas kerja yang maksimal dalam rangka mempertahankan dan memenuhi kebutuhan hidupnya.

\subsubsection{Jenis kelamin}

Jenis kelamin mempengaruhi mata pencaharian yang dilakukan. Seseorang yang berjenis kelamin laki-laki memiliki tanggung jawab yang lebih besar salah satunya dalam hal pekerjaan, dimana pihak laki-laki yang khususnya sudah menikah memiliki 
beban tanggungan keluarga yang wajib dinafkahi. Hasil penelitian menunjukkan responden yang berjumlah sembilan orang yakni seluruh karyawan CV Dwi Jaya dalam penilitian ini $100 \%$ adalah laki-laki, dilihat dari jenis pekerjaan yang membutuhkan tenaga ekstra, dan hal ini lebih dominan dimiliki oleh kamu Laki-laki.

\subsubsection{Tingkat pendidikan}

Pendidikan formal yang menjadi karakteristik responden ini merupakan jenjang pendidikan secara formal yakni sekolah yang telah dicapai atau diselesaikan responden. Pendidikan mempengaruhi proses belajar dan pola pikir. Berdasarkan hasil penelitian di CV Dwi Jaya bahwa pendidikan yang paling banyak ditempuh dan diselesaikan oleh responden yaitu tingkat SMA sebanyak enam orang, dan sisanya satu orang menamatkan pendidikannya pada tingkat SD, satu orang pada tingkat SMP dan satu orang menamatkan pendidikannya pada tingkat perguruan tinggi. Jika dilihat dari data karakteristik responden CV Dwi Jaya berdasarkan tingkat pendidikan di atas, perusahaan ini tidak mengutamakan pendidikan sebagai tolak ukur dalam merekrut karyawannya, asalkan mau bekerja keras, bisa bekerja sama dan tidak mudah menyerah adalah hal penting yang harus dimiliki oleh setiap karyawan.

\subsubsection{Jumlah tanggungan rumah tangga}

Salah satu faktor yang melatar belakangi karyawan dalam bekerja adalah jumlah tanggungan rumah tangga. Semakin banyak jumlah tanggungan rumah tangga, maka semakin banyak pula anggaran yang diperlukan seorang karyawan. Karakteristik anggota rumah tangga responden berdasarkan golongan umur di CV Dwi Jaya dibagi menjadi tiga, kelompok umur kurang dari 15 tahun sebanyak 18 (42,85\%) orang dengan pembagian berdasarkan jenis kelamin tiga $(7,14 \%)$ pria dan $15(35,71 / 5)$ wanita, kelompok umur 15 tahun sampai dengan 64 tahun sebanyak $24(57,14 \%)$ orang dengan pembagian berdasarkan jenis kelamin 13 (30,95\%) pria dan $11(26,19 \%)$ wanita, sedangkan untuk golongan umur di atas 64 tahun tidak ada. Total keseluruhan jumlah tanggungan anggota rumah tangga responden berdasarkan golongan umur sebanyak 42 (100\%) orang dengan pembagian berdasarkan jenis kelamin $16(38,09 \%)$ pria dan 26 $(61,90 \%)$ wanita. Jadi rata-rata setiap responden memiliki tanggungan sebesar 4,67 $(11,12 \%)$.

\subsection{Dinamika Kepemimpinan}

Dinamika diartikan sebagai gerak atau kelakuan yang dimiliki sekumpulan orang di masyarakat yang dapat menimbulkan perubahan dalam tata hidup masyarakat yang bersangkutan. Jadi, dapat dikatakan bahwa dinamika kepemimpinan dapat berubah dan berkembang sesuai dengan situasi kehidupan manusia yang bersifat dinamis. Hubungan manusiawi dapat berubah dan berkembang, sehingga perwujudan kepemimpinan menjadi bersifat dinamis. Dinamika kepemimpinan dalam hal ini merupakan gerak atau perkembangan yang ingin dicapai oleh sekelompok orang dalam upaya mencapai 
tujuan. Menurut Rivai (2008), dinamika kepemimpinan dalam prakteknya dipengaruhi oleh tiga faktor mencakup hubungan manusiawi yang efektif, proses pengambilan keputusan dan pengendalian kepemimpinan.

\section{Tabel 1.}

Pencapaian Skor Dinamika Kepemimpinan Direktur Dilihat dari Tiga Variabel Utama pada CV Dwi Jaya

\begin{tabular}{|c|c|c|c|}
\hline No & Dinamika kepemimpinan & $\begin{array}{c}\text { Rata-rata pencapaian } \\
\text { skor }\end{array}$ & Kategori \\
\hline \multirow[t]{3}{*}{1} & $\begin{array}{c}\text { Hubungan manusiawi yang } \\
\text { efektif }\end{array}$ & & \\
\hline & A Komunikasi yang baik & 4,35 & Sangat baik \\
\hline & B $\quad$ Suasana kerja & 4,55 & Sangat baik \\
\hline \multicolumn{2}{|c|}{ Sub Total } & 4,45 & Sangat baik \\
\hline \multirow[t]{5}{*}{2} & Proses pengambilan keputusan & & \\
\hline & A Delegasi & 4,11 & Baik \\
\hline & B Otoriter & 4,51 & Sangat baik \\
\hline & C Kendali bebas & 4,60 & Sangat baik \\
\hline & D Demokratis & 4,16 & Baik \\
\hline \multicolumn{2}{|c|}{ Sub Total } & 4,34 & Sangat baik \\
\hline \multirow[t]{4}{*}{3} & Pengendalian dalam kepemimpinan & & \\
\hline & A Kepatuhan & 4,38 & Sangat baik \\
\hline & B Penghargaan & 4,44 & Sangat baik \\
\hline & C Sanksi & 4,51 & Sangat baik \\
\hline \multicolumn{2}{|c|}{ Sub Total } & 4,44 & Sangat baik \\
\hline \multicolumn{2}{|c|}{ Dinamika Kepemimpinan } & 4,41 & Sangat baik \\
\hline
\end{tabular}

Berdasarkan pada Tabel 1 dapat dilihat bahwa dinamika kepemimpinan direktur pada CV Dwi Jaya termasuk kategori sangat baik dengan pencapaian skor rata-rata 4,41. Dan bila dilihat dari skor masing-masing variabelnya maka didapatkan bahwa hubungan manusiawi yang efektif yaitu dengan pencapaian skor rata-rata 4,45. Proses pengambilan keputusan dengan pencapaian skor rata-rata 4,34, dan pengendalian dalam kepemimpinan dengan pencapaian skor rata-rata 4,44 .

\subsubsection{Hubungan manusiawi yang efektif}

Hasil penelitian menunjukan bahwa hubungan manusiawi yang efektif dalam perusahaan Agribisnis CV Dwi Jaya termasuk kategori baik dengan pencapaian skor rata-rata 4,45 dari skor maksimal. Hubungan manusiawi yang efektif dalam penelitian ini dipengaruhi oleh dua indikator penting yaitu komunikasi yang baik dan susasana kerja, dengan skor masing-masing 4,35 dan 4,55 dari skor maksimal.

\subsubsection{Proses pengambilan keputusan}

Hasil penelitian menunjukkan bahwa proses pengambilan keputusan dalam dinamika kepemimpinan direktur CV Dwi Jaya termasuk kategori baik yaitu dengan 
pencapaian skor rata-rata 4,34 dari skor maksimal. Proses pengambilan keputusan dalam penelitian ini dipengaruhi oleh empat indikator penting yaitu delegasi dengan pencapaian skor 4,11, otoriter dengan pencapaian skor 4,51, kendali bebas dengan pencapaian skor 4,60, kemudian yang terakhir demokratis dengan pencapaian skor 4,16.

\subsubsection{Pengendalian dalam kepemimpinan}

Berdasarkan hasil penelitian menunjukkan bahwa pengendalian dalam kepemimpinan diperusahaan ini tergolong baik dengan pencapaian skor rata-rata 4,44 dari skor maksimal. Menurut hasil wawancara dengan responden kegiatan pengendalian dapat berjalan dengan baik karena dalam hal ini manajer selalu mematuhi dan bersedia mewujudkan program kerja dari para karyawannya. Kepatuhan dalam penelitian ini dengan pencapaian skor rata-rata 4,38 dari skor maksimal. Manajer juga memberikan penghargaan dan sanksi dalam pelaksanaan kepemimpinannya untuk menjalin hubungan kerja yang efektif melalui kerjasama dengan orang-orang yang dipimpinnya. Pemberian penghargaan ini diperuntukkan bagi setiap karyawan yang berprestasi. Penghargaan bisa diberikan dalam bentuk pujian terhadap hasil kerja karyawan dan bisa juga berupa materi sesuai dengan hasil pekerjaannya. Sanksi diperuntukkan bagi setiap karyawan yang melakukan kesalahan maupun penyelewengan terhadap peraturan yang berlaku. Bagi karyawan yang melakukan kesalahan ringan akan diberikan peringatan oleh manajer, namun peringatan ini diberikan secara kekeluargaan agar karyawan yang melakukan kesalahan mau menerima dengan hati terbuka. Manajer dalam pelaksanaan pengendalian juga memberikan ganjaran yang setimpal kepada karyawan yang berprestasi. Ganjaran yang dimaksud merupakan bagian dari sanksi yang bersifat positif, sedangkan hukuman merupakan sanksi yang bersifat negatif. Penghargaan dan sanksi diperoleh skor masing-masing yaitu 4,44 dan 4,51 dari skor maksimal.

\section{Simpulan dan Saran}

\subsection{Simpulan}

Berdasarkan hasil penelitian dan pembahasan dapat diambil kesimpulan sebagai berikut.

1. Dinamika kepemimpinan direktur dalam perusahaan yang ada pada perusahaan pembudidayaan dan penjualan benih ikan CV Dwi Jaya termasuk kategori sangat baik dengan pencapaian skor rata-rata 4,41 dari skor maksimal. Dinamika kepemimpinan direktur ini di dukung oleh hubungan manusiawi yang efektif, prosespengambilan keputusan dan pengendalian dalam kepemimpinan dalam kondisi yang baik.

2. Tiga variabel yang digunakan dalam dinamika kepemimpinan di CV Dwi Jaya terbukti sangat baik, hal ini dapat dilihat dari skor pada variabel hubungan manusiawi yang efektif dengan pencapaian skor 4,45, proses pengambilan keputusan dengan pencapaian skor 4,34, dan pengendalian dalam kepemimpinan 
dengan pencapaian skor 4,44, maka dapat disimpulkan bahwa ketiga variabel tersebut tergolong sangat baik.

\subsection{Saran}

Saran yang dapat penulis berikan terkait penelitian ini sebagai berikut.

1. Dinamika kepemimpinan di CV Dwi Jaya sudah tergolong sangat baik, oleh karena itu diharapkan direktur mampu mempertahankan kinerjanya sebagai pemimpin dalam perusahaan agar menimbulkan rasa nyaman dan aman bagi para karyawan, sehingga mempengaruhi hasil kerja yang lebih baik bagi perusahaan.

2. Pendelegasian dalam variabel proses pengambilan keputusan tergolong rendah diantara indikator yang lain meskipun masih tergolong baik, hal ini dikarenakan direktur sering mendelegasikan atau melimpahkan wewenang pada karyawannya pada saat-saat tertentu, namun para karyawan terkadang masih mengalami kesulitan dalam melaksanakan tugasnya, diharapkan direktur sebagai pemimpin perusahaan mampu turut membimbing para karyawan agar tercapainya tujuan perusahaan dengan baik.

\section{Daftar Pustaka}

Ananta, Aris \& Anwar Evi.1994. Proyeksi Penduduk dan Angkatan Kerja di Indonesia.Jakarta: Lembaga Demografi, Fakultas Ekonomi, Universitas Indonesia.

James, A. F. 1996. Manajemen. Jakarta: Erlangga.

Kartono, Kartini. 2011. Pemimpin dan Kepemimpinan. Jakarta: PT Rajawali Pers.

Muhadjir, Noeng. 1996. Metodologi Penelitian Kualitatif. Yogyakarta: Rakesarasin.

Rivai, Veithzal. 2008. Kepemimpinan dan Perilaku Organisasi (edisi ke-4). Jakarta: Rajawali pers.

Safaria, Triantoro. 2004. Kepemimpinan. Yogyakarta: Penerbit Graha ilmu.

Setiawan, Gede. 2013. Kelompok Organisasi dan Kepemimpinan. Cetakan pertama. Denpasar: Setia AGRI.

Soejono, Trimo MLS. 1995. Analisis Kepemimpinan. Bandung: PT Angkasa.

Sugiyono. 2010. Metode Penelitian Pendidikan. Bandung: ALFABETA

Yukl, Garry. 2010. Kepemimpinan dalam Organisasi. Jakarta: PT Indeks 